\title{
The Extent of Applying Value Chain Analysis to Achieve and Sustain Competitive Advantage in Jordanian Manufacturing Companies
}

\author{
Musa Abdel Latif Ibrahim Alnawaiseh ${ }^{1}$, Firas Muhammad AL-Rawashdi ${ }^{2} \&$ Mahmoud Alnawaiseh $^{3}$ \\ ${ }^{1}$ Assistant, Department of Accounting, Faculty of Management and Finance, The University of Jordan, Jordan \\ ${ }^{2}$ Faculty of Management and Finance, The University of Jordan, Jordan \\ ${ }^{3}$ Lecturer at the University of Jordan, Jordan \\ Correspondence: Musa Abdel Latif Ibrahim Alnawaiseh, Assistant, Department of Accounting, Faculty of \\ Management and Finance, The University of Jordan, Jordan. E-mail: m.nawayseh@ju.edu.jo
}

Received: May 12, 2014

doi:10.5539/ibr.v7n8p179
Accepted: May 28, 2014

Online Published: July 25, 2014

\begin{abstract}
This study aims at identifying the extent of applying value chain analysis (VCA) to achieve and sustain competitive advantage in manufacturing companies in Jordan.

To achieve the study's objectives, a questionnaire was developed and pre -tested. The population of the study consists of the (93) company which are listed in the Amman Stock Exchange of Jordan in the end of the 2012, (65) companies of them accepted to fill the questionnaires. (81.5)\% of the distributed questionnaires was received.

Descriptive and analytical statistical techniques such as frequencies, percentages, standard deviation, means, one sample $\mathrm{T}$ test and one way ANOVA were applied to test the study's hypotheses.

The study revealed the following results: manufacturing companies in Jordan apply VCA, but don't use it to achieve and sustain competitive advantage and there is no statistically significant effect of the respondents' demographic characteristics on their perceiving the importance of applying VCA to achieve competitive advantage.

The study recommends manufacturing companies in Jordan train their employees on strategic analysis of the company's internal and external environment, exercise the value chain analysis, calculate the unit cost of production and enter them in courses for achieving and sustaining competitive advantage through cost reduction and differentiation strategies.
\end{abstract}

Keywords: value chain analysis, competitive advantage, cost leadership strategy, differentiation strategy

\section{Introduction}

Companies in Jordan work in an open market and faced a solid competition. The Jordanian market full of substitute products with high quality and low prices, in addition to that, these companies produce with high costs in comparison with the internal and external competitors, especially when Jordan agreed to become one of the countries that involved in the free trading organization. If these companies try to achieve and sustain competitive advantage, they should concentrate on searching for improving its performance by reducing the product cost, increasing the product quality, reducing the production and delivery time and exercising continuously innovation.

Value chain analysis helps management in comparing the critical success factors (product cost, product quality, delivery time, innovation) with competitors and choosing the efficient strategy to face their strategies.

Value chain analysis requires: building information database for competitors, managers who have the commitment to achieve the analysis as it should be, the integration of all internal operation units with the supplementary units in the company, managers with clear vision to benefit from the opportunities and avoiding the threats in the external environment, enhance the strength points and avoid the weakness points in the internal environment.

If the companies in developing countries try to compete and to achieve and sustain competitive advantage, they should apply the new concepts and the developments in the field of strategic management and strategic analysis in order to take decisions depending on scientific, reliability and timeliness information, which is generated from applying the quantity models in management such as value chain analysis. 


\section{The Problem of the Study}

Many manufacturing companies in Jordan suffer from the effects of the competition condition in the internal markets, because they don't apply value chain analysis to achieve and sustain competitive advantage, and still depend on using traditional cost analysis to achieve competitive advantage.

\section{The Objectives and Importance of the Study}

The study aims to identify if the Jordanian manufacturing companies analyze value chain, applying it in achieving and sustaining competitive advantage, and to know if the demographic characteristics (age, educational Level and specialty) of the respondents effect on their awareness of the importance of applying VCA to achieve and sustain competitive advantage.

The important of the study comes from that this study is the first one in Jordan tries to test the relation between VCA and achieving and sustaining competitive advantage.

\section{Hypotheses}

The study aims to test the following hypotheses:

H1: manufacturing companies in Jordan don't analyze value chain.

H2: manufacturing companies in Jordan don't apply value VCA to achieve and sustain competitive advantage.

H3: manufacturing companies in Jordan don't apply VCA to sustain competitive advantage.

H4: There is no statistical significance impact of the respondents' demographic characteristics (age, educational level, and specialty) on their awareness of the importance of applying VCA to achieve competitive advantage.

\section{Literature Review}

The activities of the value chain include: research and development, design, production, marketing, distribution, and finally after-sale service. These activities are supported by a set of supplementary activities of accounting, finance, human resources and information technology (Horngren et al., 2012; Kaplinsky \& Morris, 2000; Riley, 2012; Schmitz, 2005; and Wei-Hong, 2010), each activity in the value chain added value from the customer perspective (Coulter \& Robbins, 2009; Wild et al., 2000).

Value chain analysis is a tool that helps in building a structural strategy of the company, it emphasis on the parts that creates value and the parts that doesn't do that to customers (Gerry, 2011; Thompson, 2005; Urbig \& Verlage, 2003), and improves rendering services (Lauridsen, 2011; Gabriel, 2006; and Dambudzo, 2013).

Applying value chain analysis needs to be connected with the strategic cost analysis (Hergert \& Morris, 2006; and Riisgaard et al., 2010). Strategic cost analysis is based on understanding and analyzing the cost structure in the value chain activities. So that company should establish data base system, to facilitate such analysis, and provide management with suitable information to use it in the process of selecting business' functions, activities, strategies and developing them to achieve and sustain competitive advantage. To reduce the production cost, there is two steps:

(a) Tracing customer's value of the company's products or services and developing operational objectives.

(b) Determining the activity in the value chain. With the goal of achieving competitive advantage by applying value chain analysis (Yanfang, 2012; Tchale \& Keyser, 2010), because value chain analysis helps in discovering the economic and environment aspects (Dahlstrom \& Ekins, 2006), and maximizing the value to customer is one of the critical success factors (Han, 2012).

Competitive advantage appears if company acquires the resources, technology and the abilities to make changes in products that satisfy the customers' needs, or has the ability to react quickly to the changes in the competition environment.

Porter divided competitive advantage to cost advantage and differentiation advantage. Cost advantage permits company to present products to customers at declined prices than competitors. If the company tends to compete successfully, it should satisfy the customers' needs (Kirli \& Gümǜs, 2011; Prasad \& Sahoo, 2011; and Stone house $\&$ Snowdon, 2007), adopts the new approaches in management, reduce the value chain costs by setting efficient cost, innovates the products or the production process, empower employees (Kahreh et al., 2011; Xiaoyu, 2009), enhances the delivery methods, invests in new technology (Chen, 2009), collects reliability information that helps in attaining coordinating and homogeneity between the value chain activities (Dekker, 2003), and linkage in value chain can be tuned to gain a competitive advantage (Ensign, 2001), all these activities have a clear impact on management accounting (Drury, 2006). 
Company can achieve competitive advantage by following the cost leader ship strategy (Elloumi, 2004) that concentrates on reducing the total cost of the value chain activities, or by following the product or services differentiation strategy (Shank \& Covindarajan, 2011), because strategic analysis by using value chain analysis is the base of predicting the future (Burnes, 2002).

Company can accomplish value chain analysis by implementing the following steps; firstly: defining the activities in the value chain, secondly: discussing the cost drivers for each activity in the value chain, thirdly testing the possibilities of developing and building competitive advantage that can be achieved; either through the control of cost or through the restructuring of the value chain activities. These steps can be achieved as below:

Firstly: Defining the activities in the value chain.

Company should identify the activities in the value chain, identify the activity's costs, activity's cost drivers, employees, revenues, resources and assets that is used in each activity, it should also encourage manager to control the activities that don't add value to improve their performance and take the suitable decision (Needles et al., 2002; Jain, 2011) and reveals the relationship between the inputs and outputs of the production process (Fitter \& Kaplinsky, 2001). Company can use the American approach in value chain analysis, that concentrates on market researches, design, product development, and cost reduction in the value chain activities during the product's life cycle, or use the Japanese approach which concentrates on reducing the overall cost of the product and compare target with actual costs to reduce them in the value chain activities (Walther, 2009). Using any of these approaches is an overriding the traditional system of accounting (Transtutors, 2011).

Secondly: Diagnosis the cost drivers and the factors influencing them.

The cost drivers consist of direct hours, the number of the orders, the physical measures (such as the pound, gallon, square meters), the number of raw materials' units; the fuel consumption and the number of units which are produced. Using of sole cost driver to allocate costs to products may be lead to wrong strategic decisions in allocating over head costs to the units of production. It's preferable to use machine hours to allocate costs in automation industries than labor's direct hours (Xue, 2005). Strategic cost drivers in the long run represent a sources of competitive advantage, and they help in retiring the high costs' activity, or the activity which is performed by competitors in different ways (Garrison, 2008; Antoniou et al., 2011).

Thirdly: Testing the possibilities of developing and building competitive advantage.

There are two kinds of competitive advantage: competitive advantage based on reducing costs and competitive advantage based on differentiation

Achieving competitive advantage depends on dividing business into strategic activities that added value to customer and non strategic that add nothing, or its contribution in the value creation is weak, identifying the activities in the value chain, identifying the characteristics of the activities that can be used to create value for the customer in the future (Brown, 2009), the linkage between value chain activities (Recklies, 2001) and identifying the characteristics of the product or the service that can be offered to consumer. Configuration and linking the value chain analysis helps in achieving competitive advantage (Porter, 2012; Nicovich et al., 2007; Simmister, 2003; Singh, 2012).

The competitive advantage that based on reducing costs can be achieved through reducing the costs in the value chain activities; reducing raw material costs, because it represents a high percentage of the unit cost of production, if there is a strong competition in the industry, the company may be purchased these materials from the supplier directly, who ensures continuity in supplying the company with materials in time and at the appropriate cost , reducing labor cost, reducing research and development costs, reducing the administrative costs and reducing selling costs.

Reducing the value chain activities' costs requires analyzing the cost components; the cost of raw materials, the cost of labor and factory overhead cost as follows:

(a) Analyzing the cost of raw materials.

The cost of raw materials is the main component of the production costs. Raw materials cost is affected by the company's ability to bargain and the suppliers' ability. If the company reduces the cost of raw materials in the product unit, it has the ability to lower the products prices in the face of competitors and the alternative commodities. To reduce costs, company should depend on centralization store, having the capability to bargaining, applying cost accounting, using alternative raw materials, and reducing the waiting time for shipments of new raw material. These factors help in choosing the right strategy on cost raw materials.

(b) The cost of labor. 
Labor cost represents the second important element in determining of the product's costs. If possible, reducing the cost of this component requires reducing wasted time, reducing standby time, meeting the urgent demands, transferring factory to one of the developing countries, where the wages are less.

(c) The cost of transportation and handling.

The cost of transportation and handling is also part of the cost of the production unit. If the company produces more than one product and deal with more than one client, the transporting and handling costs will decrease, and in all cases, it must compare these costs with competitors.

(d) The cost of research and development.

The high spending in research and development may not make the company leader in this area; it may be remained follower to competitors, so that company should make the benefit/cost analysis of these costs.

(e) General and administrative costs.

Administrative costs can be reduced by using centralization approach, simplifying and reducing the number of reports; reducing unnecessary packaging costs and reducing the financial details.

Developing competitive advantage also requires strategic understanding of the general factors and private factors in the company's by following the steps below:

(1) Identifying and analyzing the general factors in company's environment; economic, political, financial, social, international, logical factors, the political stability and the international relationship.

(2) Identifying and analyzing the factors in the company's environment; the structural characteristics of the industry, understanding and analyzing the five forces of Porter; suppliers, buyers, alternative commodities, new entrants to the industry, and competition (Porter 2008). These forces affect the product's sale price, the raw materials' purchase price, the product's quality, the number of purchase orders, the cost of advertising and packaging, the commission of sale, the size of the market share and the cost of the investments which is require.

Analyzing the bargaining power of suppliers requires collecting information about them (their number, the extent of integration and alliances between them). The customer analysis requires identifying the number of purchase orders, the size of the request, after-purchase services, and the loyalty to the product. Analysis of alternative goods requires identifying costs, numbers, quality, prices, associated services, and in some cases the cost of the conversion. Analyzing the threats of new entrants requires charging additional costs to prevent their entry. Analyzing competitors requires information about their experiences, the maturity of their industry, and stability. Depending on this analysis company can looking for the ways to differentiate in the areas of price, quality, services, granting of discounts sales, distributing of commission sales, the size of advertising campaigns.

(3) Supports the overall strategy of the company through the value chain analysis that contributes in developing the functional strategies that may support the overall strategy and makes the company a cost leader (Singh, 2012).

Akenbor and Okoye (2011) found in his that the relationship between value chain analysis and achieving competitive advantage was positive but insignificant.

\section{Study Methodology}

\subsection{Data Collection}

The study based on a descriptive approach by surveying the preceding studies in the same area, and based on the analytical approach, so that a questionnaire is developed to answer the study questions, and test hypotheses.

\subsection{Study's Tool}

The questionnaire consists of two parts: the first part includes paragraphs measuring demographic characteristics of the respondents in these companies, and the second part consists of the phrases that test the study's hypotheses to determine the weights of the phrases, Likert scale is used. This scale consisted of the following options: strongly agree (given five degrees), agree (given four degrees), neutral (given three degrees), disagree (given two degrees) and strongly disagree (given one degree). The reliability coefficient of the questionnaire was (0.9301), depending on the scale of Cronbach's alpha. The phrases (1-7) in the questionnaire measure the applying of value chain analysis, the phrases (8-13) measure achieving competitive advantage and the phrases (14-20) measure sustaining competitive advantage.

\subsection{Study's Population}

The study's population consists of (93) manufacturing companies that are registered in Amman Stock Exchange in Jordan, only (65) of them agreed to receive questionnaire, (53) questionnaire is received and valid for the purpose 
of the study, they represent ( $81.5 \%)$ of distributed questionnaires.

To answer the study's question and to test its hypothesis, the following statistical method are used: Measurements of descriptive statistics depending on the statistical package (SPSS) to describe the characteristics of the study sample, one sample $\mathrm{T}$ test to examine the first hypotheses and One way ANOVA test to study the other hypotheses.

\subsection{Study's Variables}

The study aims at investigating the relationship between value chain analysis (dependent variable) and achieving and sustaining competitive advantage (independent variables), questions (1-7) measure the applying of value chain analysis. The questions (8-13) measure achieving competitive advantage, and questions (14-12) measure sustaining competitive advantage (see appendix one).

\subsection{Statistic Methods and Analysis}

Descriptive statistics, arithmetic medium, standard deviations, one sample t- test and One Way ANOVA are used to analyze the demographic characteristic of the respondents; test hypotheses, One Way ANOVA (see tables 1, 2, $3,4,5,6)$.

Table 1. Demographic characteristic of the study's respondents

\begin{tabular}{llcc}
\hline Characteristic & Range & Frequency & Percentage \\
\hline Age & $20-25$ & 16 & $30.2 \%$ \\
& $26-30$ & 24 & $45.3 \%$ \\
& 31 and more & 13 & $24.5 \%$ \\
Educational level & Secondary School & 17 & $32.1 \%$ \\
& University & 25 & $47.2 \%$ \\
Specialty & High Education & 11 & $20.8 \%$ \\
& Management & 10 & $18.9 \%$ \\
& Accounting & 21 & $39.6 \%$ \\
& Economic & 9 & $17.0 \%$ \\
\hline
\end{tabular}

Table (1) reveals that $75.5 \%$ of the respondents' age between 20 to $30,68 \%$ of them have a university degree or more, $58.5 \%$ have certificate in management and accounting, of them have a knowledge in management, cost accounting and financial analysis, and experience in using quantity method in management, though this did not affect their awareness of the importance of applying the value chain analysis to achieve and sustain competitive advantage. This may be attributed to the fact that their education focuses on the theoretical education.

Table 2. Statistics of one-sample T test

\begin{tabular}{llccc}
\hline Phrases & Mean & Std. deviation & T- Value & Sig. \\
\hline (1) We determine the main activities in the value chain. & 2.509 & 1.436 & -2.487 & 0.016 \\
(2) We determine the support activities in the value Chain. & 2.736 & 1.179 & -1.631 & 0.109 \\
(3) We determine the strategic activities in the value Chain. & 2.660 & 1.270 & -1.947 & 0.057 \\
(4) We determine the non strategic activities in the value chain. & 2.642 & 1.242 & -2.102 & 0.040 \\
(5) We determine the cost drivers for each activity in the value chain. & 2.566 & 1.297 & -2.442 & 0.018 \\
(6) We analyze the cost in each activity of value chain. & 2.698 & 1.218 & -1.804 & 0.077 \\
(7) We track and control the cost of value chain in the industry. & 2.528 & 1.285 & -2.715 & 0.009 \\
Average & 2.620 & 1.229 & -2.821 & 0.006 \\
\hline
\end{tabular}

Table (2) shows the statistics of answering questions (1-7) that measure applying of VCR by Jordanian manufacturing companies. 
Table 3. Statistics of one--sample T test

\begin{tabular}{lcccc}
\hline Phrases & Mean & Std. deviation & T- Value & Sig. \\
\hline (8) We analyze the general factors in our company's environment. & 2.169 & 0.956 & -6.326 & 0.000 \\
(9) We analyze the suppliers. & 2.849 & 1.277 & -0.861 & 0.393 \\
(10) We analyze the competitors. & 2.868 & 1.127 & -0.853 & 0.398 \\
(11) We analyze the alternative commodities. & 2.736 & 1.273 & -1.510 & 0.137 \\
(12) We analyze the new entrants in our industry. & 2.528 & 1.249 & -2.748 & 0.008 \\
(13) We analyze the internal environment of the Company and manipulate any & 2.585 & 1.278 & -2.365 & 0.022 \\
weakness in it. & & & -6.452 & 0.000 \\
Average & 2.623 & 0.766 & - \\
\hline
\end{tabular}

Table 4. One way ANOVA

\begin{tabular}{ccccccc}
\hline & Sum of Square & $\mathrm{df}$ & Mean & Calculated F & Tabulated F & sig. \\
\hline Achieving competitive advantage & 5.350 & $(9,43)$ & 0.594 & 1.014 & 3.353 & 0.444 \\
\hline
\end{tabular}

Tables (3) and (4) appear the statistics of answering questions (8-13) that measure the second hypothesis.

Table 5. Statistics of one-sample T test

\begin{tabular}{llccc}
\hline Phrases & Mean & Std. deviation & T- Value & Sig. \\
\hline (14) We innovate our products. & 2.491 & 1.353 & -2.740 & 0.008 \\
(15) We improve our production process. & 2.472 & 1.137 & -3.383 & 0.001 \\
(16) We benefit from economic of large production. & 2.528 & 1.234 & -2.782 & 0.008 \\
(17) We concentrate on the product quality. & 2.509 & 1.265 & -2.823 & 0.007 \\
(18) We provide good services to our customers. & 2.056 & 1.045 & -6.570 & 0.000 \\
(19) We concentrate on providing products with lower prices. & 2.415 & 1.117 & -3.813 & 0.000 \\
(20) We concentrate on use the new technology. & 2.604 & 1.349 & -2.138 & 0.037 \\
Average & 2.431 & 1.214 & -2.716 & 0.009 \\
\hline
\end{tabular}

Table 6. One way ANOVA

\begin{tabular}{lcccccc}
\hline & Sum of Square & df & Mean & Calculated F & Tabulated F & sig. \\
\hline Sustaining competitive advantage & 24.853 & $(9,43)$ & 9.761 & 2.283 & 3.353 & 0.033 \\
\hline
\end{tabular}

Tables (5) and (6) show the statistics of answering question that measure the third hypothesis.

Table 7. One way ANOVA

\begin{tabular}{lcccccc}
\hline Variables & Sum of Squares & Mean square & Freedom degrees & Calculated F & Tabulated F & sig. \\
\hline Age & 7.179 & 1.589 & $(2,50)$ & 1.289 & 19.5 & 0.285 \\
Education level & 0.527 & 0.254 & $(2,50)$ & 0.205 & 19.5 & 0.815 \\
Specialty & 7.096 & 2.365 & $(3,49)$ & 2.007 & 2.289 & 0.125 \\
\hline
\end{tabular}

Table (6) shows the effect of demographic characteristics (age, educational Level and specialty) of the respondents on their awareness of the importance of applying VCA to achieve and sustain competitive advantage." and testing the second hypothesis. 


\section{Testing Hypotheses}

\section{H1: Manufacturing companies in Jordan don't analyze value chain.}

Table (2) reveals that the general average of the respondent's answers on the phrases that measure applying value chain analyses by the manufacturing companies in Jordan (2.620) is less than the critical value of the tool (3), and it also, reveals that the absolute value of computed $t$ (2.821) is larger than the tabulated value of $t$ (1.674), so that this hypothesis is rejected. This means that the respondents in these companies analyze the value chain activities.

\section{H2: Manufacturing companies in Jordan don't apply value chain analysis to achieve competitive advantage.}

Table (4) reveals that the computed value of $\mathrm{f}$ (1.014) is less than the tabulated $\mathrm{f}$ (3.353), so that this hypothesis is accepted. This means that the respondents in these companies don't apply the value chain analysis to achieve competitive advantage.

\section{H3: Manufacturing companies in Jordan don't apply value chain analysis to sustain competitive advantage.}

Table (6) reveals that the computed value of $\mathrm{f}$ (2.283) is less than the tabulated value of (3.353), so that this hypothesis is accepted. This means that the respondents in these companies don't apply the value chain analysis to sustain competitive advantage.

\section{H4: There is no significant effect of the respondents' demographic characteristics (age, academic level and specialty) on their awareness of the importance of applying the value chain analysis to achieve and sustain competitive advantage.}

Table (7) reveals that the calculated values of $f$ for the variables (age, educational level and Specialty) are less than the tabulated values of $\mathrm{f}$. This means that there is no significant effect of these variables on the respondents' awareness of the importance of applying value chain analysis to achieve and sustain competitive advantage.

\section{Conclusions}

Manufacturing companies in Jordan suffer from strong competition caused by the entrance of Jordan on the free trading organization, it also suffers from the lack of expertise in using value chain analysis to achieve and sustain competitive advantage.

The study revealed that the respondents in Jordanian manufacturing companies analyze value chain, but they didn't use it to achieve and sustain competitive advantage. It showed also that the respondents' demographic characteristics also, didn't have an affect on their awareness of the importance of applying value chain analysis in achieving and sustaining competitive advantages. The cause of don't use the chain value analysis in a achieving and sustaining competitive advantage is that $68 \%$ of the officers have a university degree or more, $58.5 \%$ of them have certificate in management and accounting, only $39.8 \%$ of them have a knowledge in management, cost accounting or managerial accounting, financial analysis and have an experience in using quantitive methods in management, so that $60.2 \%$ didn't have some knowledge and experience in using value chain analysis to reduce the costs of value chain activities or improve the quality of the products in the road to achieve differentiation products.

The results of the study agree with the studies' results of Yang Fang (2012), Han (2012), Singh (2012), Jain (2011), Akenbor C. and Okoye E., (2011), Chen (2009), Fearne (2009), Dahlstrom and Ekins (2006), Elloumi (2004), Dekker (2003), Simister (2003), Burnes (2002), and, Needles (2002) in analyzing value chain analysis but disagree with the results of these studies in using value chain analysis to reduce of the value chain activities and achieve or sustain competitive advantage.

\section{Recommendations}

The study recommends Jordanian manufacturing companies to train their employees on strategic analysis of the company's internal environment and external, exercise the value chain analysis, calculate the unit cost of production and enter them in courses for achieving and sustaining competitive advantage through cost reduction and differentiation strategies.

\section{References}

Akenbor, C., \& Okoye, E. (2011). An Empirical Investigation of Value-Chain Analysis and Competitive Advantage in the Nigerian Manufacturing Industry. An International Multidisciplinary Journal, Ethiopia, 5(6), 188.

Antoniou, P. H., Levitt, C. E., \& Schreihans, C. (2011). Managing Value Chain Strategy. Interdisciplinary Journal 
of Contemporary Research in Business, 3(8). Retrieved from http://www.aabri.com

Brown, G. (2009). Value Chain, Value Stream, Value Net and Value Delivers Chains (p. 7). Retrieved from http://www.trends.com

Burnes, S. (2002). The mobile commerce value chain: analysis and future development. International Journal of Information Management, 22(2), 90-108.

Chen, S. (2009). Service Culture and Its Impact on Service Innovation: Based on the Model of Service Value Chain. International conference on Management and Service Science (pp. 20-22), Tongji University, Shanghai, China.

Coulter, M., \& Robbins, S. (2009). Management (10th ed., p. 447). Prentice Hall, New Jersey.

Dahlstrom, K., \& Ekins, P. (2006). Combining Economic and Environment Dimensions: Value chain analysis of UK Iron steel Flows. Ecological and Economics, 58(3), 507-519. http://dx.doi.org/10.1016/j.ecolecon.2005.07.024

Dambudzo, I. (2013). Application of value chain analysis Frame work to enhance understanding of competitive advantage at an open and Distance learning (ODL) Institution. Global Advanced Research Journal of Education Research and Review, 2(3), 60-69.

Dekker, H. (2003). Value chain analysis in inter firm relationships: a field study. Management Accounting Research, 14(1). http://dx.doi.org/10.1016/S1044-5005(02)00067-7

Drury, C. (2006). Management Accounting for Business (3rd ed., pp. 6-7). Thomson Learning, London. Retrieved from http://en.wikipedia.org/wiki/File:Porter_Value_Chain.png

Elloumi, F. (2004). Value Chain Analysis: A strategic Approach to Online Learning (p. 18). Athabasca University,

Ensign, P. C. (2001). Value Chain Analysis and Competitive Advantage: assessing Strategic Linkage and interrelationships. Journal of General Management, 2(1), 18-42.

Fearne, A., Soosay, C., Stringer, R., Umberger, W., Dent, B., Camilleri, C., Henderson, D., \& Mugford, A. (2009). Sustainable Value Chain Analysis: a case study of South Australian Wine, Government of South Australia. Retrieved from http//www.gobookee.org

Fitter, R., \& Kaplinsky, R. (2001). Who gains from product rents as the Coffee Market, becomes more differentiated? A value chain analysis. IDS Bulletin, 32(3), 69-82. http://dx.doi.org/10.1111/j.1759-5436.2001.mp32003008.x

Gabriel, E. (2006). Value Chain For Service: a new dimension of "Porter's value chain". IMS International Journal.

Garrison, Ray H., et al. (2008). Managerial Accounting (12th ed., p. 12). McGraw-Hill, Boston.

Gerry, H. (2011). Performing Value Chain Analysis. Retrieved from http://Steven Clark .com

Han, R. (2012). The Analysis of IKEA's Value Chain Management Strategy (p. 211). Second International Conference on Business Computing and Global Information.

Hergert, M., \& Morris, D. (2006). Accounting data for value chain analysis. Strategic Management Journal, 10(2).

Horngren, C., Dater, M., \& Rajan, M. (2012). Cost Accounting: A managerial Emphasis (14th ed., p. 28). Person Education Limited, England.

Jian, J. (2011). The research for mobile e-commerce value chain model. International conference on $\mathrm{E}-\mathrm{Business}$ and E-Government (p. 1), 6-8 May 2011, Chongqing university, China.

Kahreh, M., Ahmadi, H., \& Hashemi, A. (2011). Achieving Competitive advantage through empowering employees: an empirical study.

Kaplinsky, R., \& Morris, M. (2000). A hand book for Value Chain Research, prepared for the IDRC. Retrieved from http://www.global value chain.org

Kirli, M., \& Gümǜs, H. (2011). The Implementation of strategic management accounting based on value chain analysis: value chain. International Journal of Social Sciences and Humanity Studies, 3(1), 307.

Lauridsen, B. (2011). Shifting the Paradigm: Value-Chain Analysis Applied to Online Learning La Jolla, CA. Retrieved from http://etec.hawaii.edu/proceedings

Needles, B., Power, M., \& Crosson, S. (2002). Financial Managerial Accounting (p. 841). Houghton Mifflin 
Company, Boston.

Nicovich, S., Dibrell, C., \& Davis, P. (2007). Integration of value chain position and Porter's (1980) competitive strategies into the market orientation conversation: An examination of upstream and downstream activities. The Journal of Business and Economic Studies, 13(2), 91-108.

Porter, M. (2008). The five competitive forces that shape strategy. Harvard Business Review, 86(1), 78-93. Retrieved from http://search.ebscohost.com

Porter, M. (2012). Strategy and the New Competitive Advantage: Creating Share Value (p. 4). Harvard Business School, Boston.

Prasad, V., \& Sahoo, P. (2011). Competitive advantage in Mobile Phone Industry: Focus on value chain and core competency. International Journal of computer Science and Communication, 2(2), 616.

Recklies, D. (2001). The value chain, Recklies Management Project GmbH. Retrieved from http://www.theanager.org

Riisgaard, L., Bolwig, S., Ponte, S., du Toit, A., Halberg, N., \& Matose, F. (2010). Integrating Poverty and Environmental Concerns into Value chain Analysis: A Strategic Framework and Practical Guide. Development Policy Review, 28(2), 195-216. http://dx.doi.org/10.1111/j.1467-7679.2010.00481.x

Riley, J. (2012). Value Chain Analysis. Retrieved from http://www.tutor 2u.net

Schmitz, H. (2005). Value Chain Analysis for Policy Makers and Practitioners, International Labor Organization. Retrieved from http:// Scholar/Google.Com

Shank, J., \& Covindarajan, V. (2011). Strategic Cost Management and the Value Chain.

Simister, P. (2003). Using Value Chain Analysis to create competitive Advantage. Retrieved from http://www.profitablegrowth strategy.org

Singh, P. (2012). Management of Business Process Can Help in Organization Achieve Competitive Advantage. International Management Review, 8(2).

Stonehouse, G., \& Snowdon, B. (2007). Competitive advantage revisited: Michael Porter on strategy and competitiveness. Journal of Management Inquiry, 16(3), 256-273. http://dx.doi.org/10.1177/1056492607306333

Tchale, H., \& Keyser, J. (2010). Quantitative Value Chain Analysis: An Application to Malawi. The world Bank Africa, Region Agricultural and Rural Unit.

Thompson, A., Gamble, J., \& Strickland, J. (2005). Strategy: Winning in the market place (2nd ed., p. 95). New York: The McGraw-Hill Companies.

Transtutors. (2011). Bring Out the Contrasting Features of Value Chain Analysis and Traditional Accounting Systems. Retrieved from http://www.transtutors.com/homeworkhelp/

Urbig, D., \& Verlage, S. (2003). The value chain's values: Interpretations and Implications for firm and industry analysis. In Proceedings of Perspectives in Business Informatics Research (BIR) (pp. 1-15), Berlin.

Walther, L., \& Skousen, C. (2009). Managerial and Cost Accounting (pp. 79-80).

Wei-Hang, X. (2010). An Analysis of the Product Positioning Development Strategy of TV Shopping on the Basis of Value Chain, Management and Services Science. International conference conducted 24-26 Aug. 2010 on East China University, Shanghai.

Wild, J., Shaw, K., \& Chiappetta, B. (2005). Financial and Managerial Accounting: Information for decisions (p. 592). McGraw-Hill, Irwin, Boston.

Xiaoyu, L. (2009). Research on Chinese renewable energy's chain development strategy based on vis analysis. International conference in technology and innovation, 12-14 OCT.2009, North China Electric Power University, Beijing, China, IEEE Xplore Digital Library.

Xue, Z. (2005). Using value chain analysis to make a choice of international marketing strategy (pp. 5-8). Master Thesis, Nurtingen: Zurich University of Applied Science.

Yanfang, W. (2012). Research on Cost Strategies in Railway Construction Business Based on Value Chain Analysis. Management Science and Engineering, 6(3), 59. Canadian Research \& Development Center of Sciences and Cultures. 


\section{Copyrights}

Copyright for this article is retained by the author(s), with first publication rights granted to the journal.

This is an open-access article distributed under the terms and conditions of the Creative Commons Attribution license (http://creativecommons.org/licenses/by/3.0/). 